\title{
Morphometric evaluation of the spermatogenesis in trahira Hoplias malabaricus (Bloch) (Characiformes, Erythrinidae)
}

\author{
Paula M. Bizzotto ${ }^{1} \&$ Hugo P. Godinho ${ }^{2}$ \\ 1 Programa de Pós-graduação em Zoologia de Vertebrados, Pontifícia Universidade Católica de Minas Gerais. \\ 30535-610 Belo Horizonte, Minas Gerais, Brasil. E-mail: bizzottopaula@yahoo.com.br \\ 2 Rua João A. Cardoso 192, 31310-390 Belo Horizonte, Minas Gerais, Brasil.
}

\begin{abstract}
The Erythrinidae trahira, Hoplias malabaricus (Bloch, 1794), is widespread throughout South America river basins. We determined Sertoli cell supporting capacity (ratio of primary spermatocytes: Sertoli cells and spermatids: Sertoli cells), meiotic index (ratio of spermatids: primary spermatocytes) and the number of spermatogonial mitotic generations of this fish. The fish were captured in the Igarapava reservoir, Grande River, Alto Paraná River basin, Brazil. Testis fragments of three sexually mature trahiras were fixed in $5 \%$ buffered glutaraldehyde solution and embedded in glycol methacrylate. Serial sections of 2 and $3 \mu \mathrm{m}$ in thickness were stained with $0.5 \%$ toluidine blue. Histological counts from cysts of primary spermatocytes and spermatids revealed, respectively, $326 \pm 99$ and $468 \pm 73$ nuclei of these cells. Sertoli cell supporting capacity was considerably higher for spermatids $(113.3 \pm 16: 1)$ when compared to primary spermatocytes $(71 \pm 5: 1)$. Between eight and ten spermatogonial generations were formed to give rise to primary spermatocytes. These values were within the generation range of those already found in freshwater teleosts of external fertilization. Correlation between the number of Sertoli cells and primary spermatocytes per cyst, and Sertoli cells and spermatids per cyst were statistically significant $(p<0.05)$. KEY WORDS. Sertoli cell; spermatogonial generations; teleost testis morphometry.
\end{abstract}

\begin{abstract}
RESUMO. Avaliação morfométrica da espermatogênese da traíra Hoplias malabaricus (Bloch) (Characiformes, Erythrinidae). A traíra, Hoplias malabaricus (Bloch, 1794), da família Erythrinidae, encontra-se espalhada pelas bacias fluviais da América do Sul. Determinou-se a capacidade de suporte das células de Sertoli (espermatócitos primários: células de Sertoli e espermátides: células de Sertoli), índice meiótico (espermátides: espermatócitos primário) e o número de gerações mitóticas de espermatogônias desse peixe. Os indivíduos foram capturados no reservatório de Igarapava, rio Grande, bacia do Alto Paraná, Brasil. Fragmentos dos testículos de três traíras sexualmente maduras foram fixados em glutaraldeído a $5 \%$, e incluídos em metacrilato. Cortes seriados de 2 e $3 \mu \mathrm{m}$ de espessura foram corados em azul de toluidina a $5 \%$. Contagens histológicas feitas em cistos de espermatócitos primários e espermátides revelaram, respectivamente, $326 \pm 99$ e $468 \pm 73$ núcleos destas células. A capacidade de suporte das células de Sertoli foi consideravelmente mais alta para espermátides (113,3 $\pm 16: 1)$ do que para espermatócitos primários $(71 \pm$ 5:1). Ocorreram entre oito e dez gerações de espermatogonias antes de darem origem aos espermatócitos primários. Esses valores encontravam-se dentro da amplitude de gerações já registrada para teleósteos de água doce de fertilização externa. Correlações entre o número de células de Sertoli por cisto e de espermatócitos primários e entre células de Sertoli e espermátides por cisto foram estatísticamente signficativas $(p<0,05)$.
\end{abstract}

PALAVRAS-CHAVE. Célula de Sertoli; gerações de espermatogônias; morfometria testicular.

The Erythrinidae trahira, Hoplias malabaricus (Bloch, 1794), is widespread throughout South America river basins (OYAKAWA 2003). It is characterized by fractional spawning, nest building in shallow and quite waters, parental care, low fecundity and yielding low volumes of milt (Querol et al. 2003). Although both parents build the nest for spawning, only the male takes care of the offspring (SATO et al. 2003). The species exhibits a striking karyotype diversity which points out to a species- complex with distinct evolutionary units (Bertollo et al. 2000, VICARI et al. 2005).

Vertebrate testis shows a germinal compartment represented by seminiferous tubules (= seminiferous lobules), in which two cell types are found: somatic and germinal. In most teleosts, spermatogenesis takes place within cysts. All germinal cells within a cyst are in the same developmental stage, bound by intercellular bridges and synchronically divided (VILELA et al. 2003). The 
cyst wall consists of Sertoli cell whose projections are related to the germinal cells forming Sertoli/germinal cell units (Schulz \& MiURA 2002). In mammals, the ratio germinal cells: Sertoli cells (which expresses the Sertoli cell supporting capacity) is relatively defined for each species (França \& Russell 1998). Compared to mammals, Sertoli cell supporting capacity in the teleost Nile tilapia is remarkably high (MATTA et al. 2002). The number of mitotic divisions during spermatogenesis to form primary spermatocytes is also species-specific (Schulz \& Miura 2002). Although the knowledge of the number of such mitotic divisions is important to understand regulation mechanisms of the spermatogenic process (DE RooIJ \& Russell 2000), few reports are available on the subject in teleosts. Considering the large fish fauna diversity, quantitative data on the spermatogenic process, in teleosts in general, are scarce, differently from other vertebrate groups, especially mammals (França \& Russell 1998, MatTa et al. 2002).

The present work was aimed at determining the number of primary spermatocytes and spermatids held by the respective cysts of the trahira in order to estimate: i) germinal cells: Sertoli cells ratio, ii) spermatids: primary spermatocytes ratio and iii) number of spermatogonial generations leading to primary spermatocyte production. To our knowledge, this is the first study aimed to establish the number of spermatogonial generations in a Neotropical fish.

\section{MATERIAL AND METHODS}

The fish used in this study were captured in the Igarapava reservoir, Grande River, Alto Paraná River basin, Brazil (1959' $\left.36^{\prime \prime} \mathrm{S}, 47^{\circ} 45^{\prime} 32^{\prime \prime} \mathrm{W}\right)$. Testis fragments of approximately $3 \mathrm{~mm}$ in thickness of three sexually mature trahiras (420-970 g, body weight; $31.6-42.3 \mathrm{~cm}$, total length) were used. The fragments were fixed by immersion in 5\% buffered glutaraldehyde solution, $0.1 \mathrm{M}$ phosphate buffer, $\mathrm{pH} 7.3$, and then routinely embedded in glycol methacrylate. Serial sections of 2 and $3 \mu \mathrm{m}$ in thickness were stained with $0.5 \%$ toluidine blue for histological and morphometric analyses. The slides were analysed under a light microscope Olympus CBA and the documentation performed with a photomicroscope Olympus BX 50.

Nuclei of Sertoli cells, primary spermatocytes and spermatids at the intermediate phase of spermiogenesis were counted in five cysts from each of the three fish used in this study. The counts were performed in serial sections of $3 \mu \mathrm{m}$ thick for primary spermatocytes and $2 \mu \mathrm{m}$ thick for spermatids after selecting cysts entirely encompassed by the serial sections (MatTa et al. 2002). Thirty primary spermatocyte and spermatid nuclei were measured in each fish. Care was taken not to count a same nucleus twice. The data allowed us to determine the ratio of primary spermatocytes: Sertoli cells, the supporting capacity of Sertoli cells (i.e., the ratio of spermatids: Sertoli cells) and the meiotic index (i.e., the ratio of spermatids: primary spermatocytes). The number of mitotic divisions (generations) based on the number of primary spermatocytes per cyst was also estimated. The presence of apoptotic germinal cells was recorded. The apoptotic cells were morphologically characterised as darker staining cells as this is the usual condition for these cells embedded in plastic and stained with toluidine blue (Russell et al. 1990).

All basic statistic analyses were performed with the program Minitab 12.2. The degree of linear relationship between the number of germ cells and Sertoli cells per cyst was evaluated with the help of Pearson's correlation test. The significance level (p) of 0.05 was adopted throughout.

\section{RESULTS}

Testis of adult, reproductive active trahiras showed cysts of all germ cell types, i.e. spermatogonia (Fig. 1, SPG), primary spermatocytes (Fig. 1, PST), secondary spermatocytes (Fig. 1, SST) and spermatids (Fig. 1, SPD), randomly distributed in the seminiferous tubules (= lobules). Sertoli cell extensions made the cyst wall (Fig. 1, S) and spermatozoa were in the lumen (Fig. 1, Z). The nuclear sizes were $4.5 \pm 0.2 \mu \mathrm{m}$ and $2.3 \pm 0.1 \mu \mathrm{m}$, respectively, for primary spermatocytes and spermatids. The number of Sertoli cells/cyst, primary spermatocytes/cyst and spermatids/ cyst is shown in table I. A few primary spermatocytes were seen undergoing apoptosis. A significant correlation between the number of primary spermatocytes and Sertoli cells per cyst $(\mathrm{r}=$ $0.87 ; \mathrm{p}<0.05)$ and spermatid and Sertoli cell per cyst $(\mathrm{r}=0.80 ; \mathrm{p}$ $<0.05)$ was found.

The ratio of primary spermatocytes:Sertoli cells and spermatids:Sertoli cells and the meiotic index are presented in table I. Sertoli cells could support approximately 62\% more spermatids $(113.3 \pm 16: 1)$ than primary spermatocytes $(71 \pm 5$ : $1)$. One primary spermatocyte gave rise to almost two spermatids. The number of primary spermatocytes/cyst, i.e. $326 \pm 99$ (Tab. I) suggested that theoretically at least eight spermatogonial generations (range $=8-10$ ) were completed before giving rise to primary spermatocytes.

Table I. Cell parameters of trahira primary spermatocyte and spermatid cysts (mean \pm standard error; three fish, five cysts of each germinal cell type/fish; values in parenthesis indicate range).

\begin{tabular}{lc}
\hline \multicolumn{1}{c}{ Parameter } & Value \\
\hline Cysts of primary spermatocytes & \\
Number of Sertoli cells & $4.5 \pm 1.1(1-9)$ \\
Number of germinal cells & $326 \pm 99(129-627)$ \\
Cysts of spermatids & \\
Number of Sertoli cells & $4.3 \pm 0.8(1-12)$ \\
Number of germinal cells & $468 \pm 73(150-970)$ \\
Sertoli cell supporting capacity & \\
Primary spermatocytes: Sertoli cell & $71 \pm 5: 1$ \\
Spermatids: Sertoli cell & $113,3 \pm 16: 1$ \\
Meiotic index & \\
Spermatids: primary spermatocyte & $1.9 \pm 0.8: 1$ \\
\hline
\end{tabular}




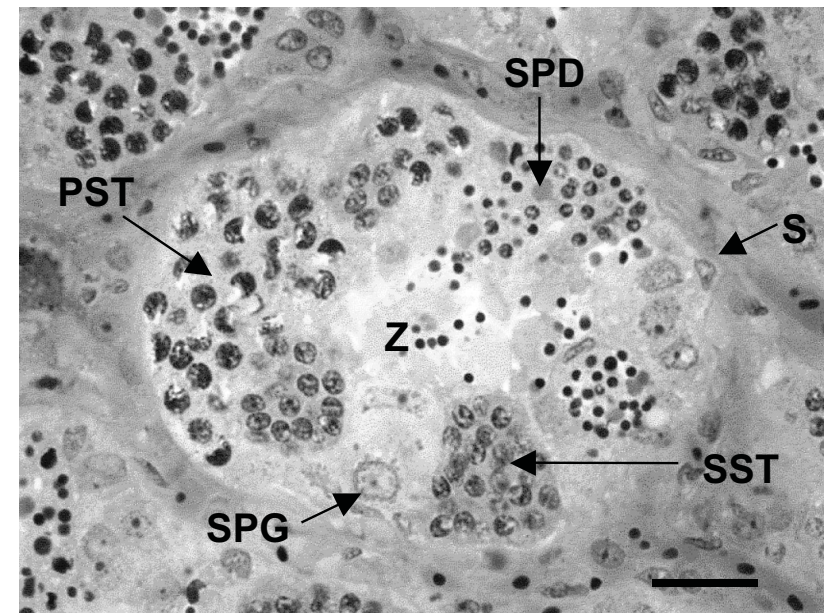

Figure 1. Transverse section of a seminiferous tubule (= lobule) of trahira Hoplias malabaricus. Cysts of spermatogonia (SPG), primary spermatocytes (PST), secondary spermatocytes (SST) and spermatids (SPD) in the trahira seminiferous tubule wall; Sertoli cell nuclei $(S)$ located at the cyst periphery; seminiferous tubule lumen contains few spermatozoa (only spermatozoon heads, stained in black, are seen, Z). Bar $=25 \mu \mathrm{m}$.

\section{DISCUSSION}

The cystic arrangement of the trahira testis was similar to that found in most teleosts (BILlard 1986, MiUra 1999, Grier $\&$ NeIDIg 2000) and its histology corresponded to the description given by MARQUES et al. (2000). The seminiferous tubule arrangement is of the anastomosing lobular type (PARENTI \& GRIER 2004) in which the germinal compartment does not end in the testis periphery but forms highly branched loops or tubules. The number of germinal cells supported by the Sertoli cell is a good indication of the functional efficiency of this somatic cell (MATTA et al. 2002). The ratio spermatids: Sertoli cells in the trahira of the present work was very similar to that of the teleost Nile tilapia Oreochromis niloticus (MATTA et al. 2002). Our findings corroborated the statement that the teleost cystic arrangement is more efficient than that of mammals in which the Sertoli cells are dispersed in the seminiferous epithelium (MatTa et al. 2002, Vilela et al. 2003). In the Nile tilapia, approximately 2.5 spermatids are formed from each primary spermatocyte, which represents less than $40 \%$ of cell loss (MATTA et al. 2002). In trahira, cell loss reached a higher value being slightly above $50 \%$. In mammals, apoptosis of germinal cells is part of the physiological spermatogenesis activity, occurring spontaneously in several stages of cell development (RoosenRUNGE 1977). It plays an important role in homeostasis during the spermatogenic process leading to spermatic production characteristics of different animal groups (FRANÇA \& Russell 1998, Chaves-Pozo et al. 2005, SAsso-Cerri et al. 2006). The occurrence of apoptosis in primary spermatocyte cysts of the trahira rises the question, not addressed in this paper, of its role the spermatogenic process of this teleost.

Knowledge of the number of spermatogonial generations is essential to better understand the regulatory mechanisms of spermatogenesis (DE RooIJ \& Russell 2000). In mammals, from two to six mitotic divisions are necessary to produce primary spermatocytes (França \& Russell 1998). Studies of teleosts with external fertilization indicate that the process takes five to ten generations of spermatogonia to produce primary spermatocytes (Miura 1999, Miura et al. 1991, Ando et al. 2000, MatTa et al. 2002). In the guppy, Poecilia reticulata, a species of internal fertilization, 14 spermatogonial divisions are necessary to produce primary spermatocytes (BILLARD 1986). Concerning primary spermatocytes, approximately $50 \%$ of the trahira cysts contained a number of cells derived from, at least, eight mitotic divisions; in the remaining cysts such numbers were either nine or ten. It is still not clear whether the number of mitotic divisions is environment-controlled and/or an inherent property of stem-spermatogonia (MIURA 1999). Determination of the spermatogenic efficiency in different groups of fish would be valuable to better understand their reproductive strategies and related ecological issues.

\section{ACKNOWLEDGEMENTS}

To R. Miranda for his efficiency to prepare the serial sections; to the Program of Incentive to Research (FIP Program), Pontifical Catholic University of Minas Gerais, for financial support.

\section{REFERENCES}

Ando, N.; T. Miura; M.R. Nader; C. Miura \& K. Yamauchi. 2000. A method for estimating the number of mitotic divisions in fish testes. Fisheries Science 66: 299-303.

Bertollo, L.A.C.; G.G. Born; J.A. Dergam; A.S. Fenocchio \& O. Moreira-FilHo. 2000. A biodiversity approach in the neotropical Erythrinidae fish, Hoplias malabaricus. Karyotypic survey, geographic distribution of cytotypes and cytotaxonomic considerations. Chromosome Research 8: 603-613.

BiLlard, R. 1986. Spermatogenesis and spermatology of some teleost fish species. Reproduction Nutrition Dévelopment 26: 877-920.

Chaves-Pozo, E.; V. Mulero; J. Meseguer \& A.G. Ayala. 2005. An overview of cell renewal in the testis throughout the reproductive cycle of a seasonal breeding teleost, the gilthead seabream (Sparus aurata L.). Biology of Reproduction 72: 593-601.

DE RooIJ, D.G. \& L.D. RusselL. 2000. All you wanted to know about spermatogonia but were afraid to ask. Journal of Andrology 21: 776-798.

FrançA, L.R. \& L.D. RusselL. 1998. The testis of domestic animals, p. 197-219. In: Martínez-García, F. \& J. Regadera (Eds.). Male reproduction: a multidisciplary overview. Madrid, Churchill Communications, 440p.

Revista Brasileira de Zoologia 24 (3): 541-544, setembro 2007 
Grier, H.J. \& C. Neydig. 2000. Gonads and gametes of fishes, p. 1-12. In: T.R. TIERSCH \& P.M. MAZIK (Eds). Cryopreservation of aquatic species. Baton Rouge, The Word Aquaculture Society, 439p.

Marques, D.K.S.; I.L. Rosa \& H.C.B. Gurgel. 2000. Descrição histológica das gônadas de traíra Hoplias malabaricus (Bloch) (Osteichthyes, Erythrinidae) da barragem do rio Gramame, Alhandra, Paraíba, Brasil. Revista Brasileira de Zoologia 17: 573-582.

Matta, S.L.P.; D.A.R. Vilela; H.P. Godinho \& L.R. França. 2002. The goitrogen 6-n-propyl-2-thiouracil (PTU) given during testis development increases Sertoli and germ cell numbers per cyst in fish: the tilapia (Oreochromis niloticus) model. Endocrinology 143: 970-978

Miura, T. 1999. Spermatogenetic cycle in fish, p. 571-578. In: E. KNOBIL \& J.D. NeIL (Eds). Encyclopedia of reproduction. London, Academic Press, vol. 4, 1297p.

Miura, T.; K. Yamauchi; H. Takahashi \& Y. Nagahama. 1991. Hormonal induction of all stages of spermatogenesis in vitro in the male Japanese eel (Anguilla japonica). Proceedings of the National Academy of Sciences USA 88: 5774-5778.

OyakaWA, O.T. 2003. Family Erythrinidae (Trahiras), p. 238-240. In: R.E. Reis; S.O. Kullander \& C.J. Ferraris JR (Eds). Check list of the freshwater fishes of South and Central America. Porto Alegre, EDIPUCRS, 729p.

Parenti, L.R. \& H.J. Grier. 2004. Evolution and phylogeny of gonad morphology in bony fishes. Integrative and Comparative Biology 44: 333-348.

Received in 10.IV.2007; accepted in 30.VI.2007.
Querol, M.V.M.; E. Querol; E. Pessano; C.L.O. Azevedo; D. TOMASSONI; L. BRAsil \& P. Lopes. 2003. Reprodução natural e induzida de Hoplias malabaricus (Bloch, 1724) em tanques experimentais, na região de Uruguaiana, Pampa Brasileiro. Biodiversidade Pampeana 1: 46-57.

Roosen-Runge, E.C. 1977. The process of spermatogenesis in animals. Cambridge, Cambridge University Press, 214p.

Russell, L.D.; R.A. Ettlin; A.P. Sinha-Hikim \& E.D. Cleggg.1990. Histological and histopathological evaluation of the testis. Clearwater, Cache River Press, 286p.

Sasso-Cerri, E.; P.S. Cerri; E. Freymüller \& S.M. Miraglia. 2006. Apoptosis during the seasonal spermatogenic cycle of Rana catesbeiana. Journal of Anatomy 209: 21-29.

Sato, Y.; N. Fenerich-Verani; A.P.O. Nuñer; H.P. Godinho \& J.R. Verani. 2003. Padrões reprodutivos de peixes da bacia do São Francisco, p. 229-274. In: H.P. GodinHo \& A.L. GodinHo (Eds). Águas, peixes e pescadores do São Francisco das Minas Gerais. Belo Horizonte, PUC Minas, 458.

Schulz, R.W. \& T. Miura. 2002. Spermatogenesis and its endocrine regulation. Fish Physiology and Biochemistry 26: 43-56.

Vicari, M.R.; R.F. Artoni \& L.A.C. Bertollo. 2005. Comparative cytogenetics of Hoplias malabaricus (Pisces, Erythrinidae): a population analysis in adjacent hydrographic basins. Genetics and Molecular Biology 28: 103-110.

Vilela, D.A.R.; S.B.B. Silva; M.T.D. PeiXoto; H.P. Godinho \& L.R. FranÇA. 2003. Spermatogenesis in teleost: insights from the Nile tilapia (Oreochromis niloticus) model. Fish Physiology and Biochemistry 28: 187-190. 